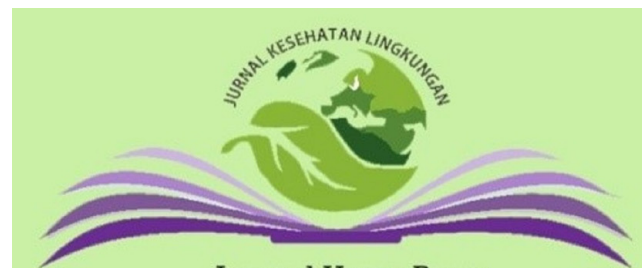

Journal Home Page:

https://e-journal.unair.ac.id/JKL

\section{Jurnal Kesehatan Lingkungan}

Vol. 13 No. 4

DOI: $10.20473 /$ jkl.v13i4.2021.219-226

ISSN: 1829 - 7285

E-ISSN: 2040 - 881X

\title{
IMPACT OF CLIMATE CHANGE ON DENGUE HEMORRHAGIC FEVER (DHF) IN TROPICAL COUNTRIES: A LITERATURE REVIEW
}

\section{Shara Nuzila Ramadhani ${ }^{*}$, Mohd. Talib Latif $^{1,2}$ \\ ${ }^{1}$ Departement of Environmental Health, Faculty of Public Health, Universitas Airlangga, Surabaya 60115, Indonesia. \\ ${ }^{2}$ Department of Earth Sciences and Environment, Faculty of Science and Technology, University Kebangsaan Malaysia,43600 Bangi, Selangor, Malaysia.}

\section{Corresponding Author:}

*) shara.nuzila.ramadhani-2017@fkm.unair.ac.ic

\section{Article Info}

Submitted

In reviewed

Accepted

2 August 2021

: 9 August 2021

Available Online

4 October 2021

31 October 2021

\section{Abstract}

Introduction: Dengue Hemorrhagic Fever (DHF) is a zoonotic disease that is most wary because the cases reported by WHO increased quite drastically from 2.4 million cases to 5.2 million cases in 2010-2019 globally. In 2020, the DHF rate increased by 953,476, and the majority occurred in tropical countries. In response to this, WHO emphasized that climate and weather variables can play an important role in predicting the DHF outbreak. This article was written to find out the impact of climate change on the incidence of DHF. Discussion: The literature review method was used in writing this article by utilizing article searches in online databases, namely PubMed, DOAJ, Proquest, and Science Direct. Amount 11 articles related to the title have been selected as literacy materials. Climatic variables consisting of temperature, rainfall, and humidity have the potential to increase the incidence of DHF. Conclusion: It can be concluded that climate change indicators can affect the breeding place of the Aedes aegypty, making the various incidence of DHF cases in tropical or subtropical countries. This can be an early warning for each region always to carry out active surveillance in detecting the risk of increasing DHF cases in certain weather.

Keywords : Weather, Dengue hemorrhagic

fever, Climate change, Tropical

Published by Fakultas Kesehatan Masyarakat

Universitas Airlangga

\section{INTRODUCTION}

Dengue hemorrhagic fever (DHF) is a vectorborne disease belonging to the climate-sensitive such as precipitation, temperature, and humidity (1) caused by four serotypes of the dengue virus, namely DEN-1, DEN-2, DEN-3, DEN-4, which are transmitted by female Aedes mosquitoes. DHF is also the fastest-spreading mosquito-borne disease globally and has a significant impact on economic, political, and social (2).

World Health Organization estimated that 390 million people are infected each year, and 3.9 billion people are at risk. From 2015 to 2019 , dengue cases in the Southeast Asia region increased by $46 \%$ (3). Several factors that influence the spread of dengue are variation in climate, economic and social demography, population growth, and changes in public health policies (3-4) which climate change has a fairly high influence. The incidence of DHF circulates every year in tropical and sub-tropical climates correlates with temperature, rainy season, and vector increase in certain seasons (5). The study conducted in Yogyakarta stated that air humidity affected the breeding places of Aedes aegypti mosquito larvae
(6). Drizzling with short intervals stimulates mosquitoes to lay eggs, making a good temperature that affects the survivability of mosquito reproduction (7). Climate change can increase the effects of vector-borne diseases on human and animal health worldwide (8).

Climate change is characterized by long-term changes in weather patterns and temperatures in a place, which can cause weather patterns to become unpredictable or erratic (9). Based on research that has been done previously for more than 50 years, human activity is the dominant factor and is also responsible for the occurrence of global warming. The phenomenon of climate change seen from temperature can be exemplified by a longer summer compared to winter (10). In tropical countries, when climate change occurs, there will also be an increase in rainfall, plant growth, and evapotranspiration which will cause a humid effect in areas experiencing global warming (11).

Between 2030 and 2050, climate change is estimated to cause 250,000 deaths per year, such as malnutrition, malaria, diarrhea, and heat stress (12). Climate change harms human health and the 
environment from various aspects, such as extremely hot weather, natural disasters, irregular rain patterns, and infection patterns (13). One of the impacts of climate change in the health aspect is that it can extend the transmission period of vectors that cause vector-borne diseases and change the geographic range of these vectors (14). Aedes mosquito is very sensitive to climatic conditions, and some studies find that climate change can increase exposure to DHF (15). Changes in climatic conditions can change the temporal-spatial distribution of vectors, especially vectors that live at low latitudes. Increasing temperature will cause the vector to move to a higher place, which becomes a new habitat for the vector. DHF spreading is higher during the rainy season when rainfall and humidity are high, so that it has the potential to cause outbreaks (16).

Efforts to improve the environment to prevent climate change on earth are goals sought to be achieved in the global action plan for Sustainable Development Goals, specifically number 13 , which states take urgent action to combat climate change and its impacts. The purpose of this paper is to analyze the correlation between climate change and the incidence of DHF in tropical or subtropical countries, based on the findings of previous research papers discussed.

\section{DISCUSSION}

From four databases, a total of 1485 articles were found, then a brief screening was carried out on the relevance of the title, abstract, and access of the articles so that the total articles obtained were reduced to 356 . The article selection stage begins with identifying and screening articles following predetermined criteria, assessing the quality of articles according to the specified eligibility until it ends in several articles used as reference material. In the article quality selection process, the assessment is carried out using a series of alloys with the Critical Appraisal Skills Program (CASP) method. Assessment using CASP is done by doing a checklist based on several types of research methods provided. The author is required to answer several questions with the answer choices "Yes", "Can't Tell", and "No". In the final result, 11 research articles have been obtained as references for literature review materials. All articles were identified as having the same goal, namely to analyse the relationship between climate change and the incidence of DHF in different areas.

Of the 11 research articles that were used as references with similar research topics, several articles stated that the prevalence of DHF and Aedes aegypti correlates with the occurrence of climate change $(n=7)$ or with climatic factors with details of temperature $(n=9)$, rainfall $(n=6)$, and humidity $(n=3)$. There are 7 out of 11 selected articles that conclude that climate change can impact the incidence of DHF or have an effect on vector life. Of the three selected climatic factors, temperature is the dominant climatic factor in influencing the incidence of DHF in various countries. For example, a study in Nepal conducted in 2018 stated that a certain temperature range describes the conditions required for mosquitoes to lay eggs and develop. It is followed by the rainfall factor discussed in 6 out of 11 articles that correlated with DHF. For example, a study stated that rainfall has a positive correlation with the incidence of DHF (17). On the humidity factor, only 3 out of 11 articles concluded that humidity affected the incidence of DHF, namely a study conducted in Latin America in 2016. In comparison, the other eight articles stated no relationship or did not discuss the humidity factor.

The majority of the research conducted to find the relationship between climate change and the potential for increased risk of dengue transmission was carried out using a case study method using several related datasets. For example, research conducted in the Southeastern United States in 2017 using the case study method. The study uses daily weather data, future climate change, and cases of dengue fever to calculate the impact of climate change on the transmission of dengue disease. A similar study using the case study method was conducted in Africa in 2020 by utilizing data on the incidence of DHF and 19 bioclimatic variables from 1950-2000, which present current climatic conditions. In addition, some literature calculates using data from the IPCC, namely RCP, which is a scenario related to climate change. As described in Table 2, five studies use the RCP model scenario to predict the effect of climate change on the incidence of DHF in a predetermined period of the year. The modeling approach in making predictions can be made in two types: the correlative or mechanistic model approach. The data is used as one of the calculation variables to estimate the impact of climate change on the incidence of DHF. Prediction of future spatial patterns regarding climate change and dengue incidence can also be made by considering the vector capacity under the same climate change scenario. These results can inform further developments regarding the early warning system for dengue virus transmission in certain areas (18). 
Table 1. Literature Review

\begin{tabular}{|c|c|c|c|c|c|}
\hline Author & Tittle & Method & Population & Result & Conclusion \\
\hline $\begin{array}{l}\text { Callan Davis, Amanda } \\
\text { K. Murphy, Hillary } \\
\text { Bambrick, Gregor J. } \\
\text { Devine, Francesca D. } \\
\text { Fentiu, Laith Yakob, et } \\
\text { al (18) }\end{array}$ & $\begin{array}{l}\text { A Regional Suitable } \\
\text { Conditions Index to } \\
\text { Forecast The Impact } \\
\text { of Climate Change } \\
\text { on Dengue Vectorial } \\
\text { Capacity }\end{array}$ & Case Study & $\begin{array}{l}\text { Gridded historical } \\
\text { climate data (2005- } \\
2018 \text { ) on six countries } \\
\text { from the TerraClimate } \\
\text { database }\end{array}$ & $\begin{array}{l}\text { The Philippines and Indonesia are } \\
\text { suitable countries for Aedes mosquitoes } \\
\text { to transmit. Temperature and rainfall } \\
\text { have a great impact on vector } \\
\text { development and propaganda of the } \\
\text { dengue virus. }\end{array}$ & $\begin{array}{l}\text { The convenience of } \\
\text { the Aedes mosquito in } \\
\text { transmitting in Southeast } \\
\text { Asia can increase or } \\
\text { decrease at any time. }\end{array}$ \\
\hline $\begin{array}{l}\text { Dave D. Chadee and } \\
\text { Raymond Martinez (31) }\end{array}$ & $\begin{array}{l}\text { Aedes aegypti (L.) in } \\
\text { Latin American and } \\
\text { Caribbean Region: } \\
\text { With Growing } \\
\text { Evidence for Vector } \\
\text { Adaptation to Climate } \\
\text { Change? }\end{array}$ & $\begin{array}{l}\text { Experimental } \\
\text { and } \\
\text { Observational } \\
\text { Studies. }\end{array}$ & $\begin{array}{l}\text { Aedes Aegypti inside } \\
\text { The Containers }\end{array}$ & $\begin{array}{l}\text { The mortality of mosquito larvae } \\
\text { and pupae reached } 67 \%-90 \% \text { at the } \\
\text { air temperature of around } 35-39.9 \\
\text { containers. Meanwhile, the dark } \\
\text { container area showed little or no } \\
\text { mortality in immature mosquitoes. }\end{array}$ & $\begin{array}{l}\text { High temperatures and } \\
\text { anthropogenic factors cause } \\
\text { the movement of adult } \\
\text { mosquitoes to find a more } \\
\text { secure nesting place. }\end{array}$ \\
\hline $\begin{array}{l}\text { Cristiam Victoriano } \\
\text { Portilla Cabrera, John } \\
\text { Josephraj Selvaraj (26) }\end{array}$ & $\begin{array}{l}\text { Geographic Shifts } \\
\text { in The Bioclimatic } \\
\text { Suitability for Aedes } \\
\text { Aegypti Under Climate } \\
\text { Change Scenario in } \\
\text { Colombia (2020) }\end{array}$ & $\begin{array}{l}\text { Case Study } \\
\text { using SDM } \\
\text { toolbox } 2.0 \text { and } \\
\text { MaxEnt } 3.4 .1 \text {, } \\
\text { and literature } \\
\text { review }\end{array}$ & $\begin{array}{l}\text { Occurrence data for } \\
\text { Aedes aegypti from } \\
\text { Global Biodiversity } \\
\text { Information Facility } \\
\text { on five geographical } \\
\text { regions at Colombia }\end{array}$ & $\begin{array}{l}\text { The variables that contributed most } \\
\text { significantly to the spread of Aedes } \\
\text { aegypti (sequentially) were altitude, } \\
\text { isothermal, and precipitation. }\end{array}$ & $\begin{array}{l}\text { Areas in Colombia that are } \\
\text { vulnerable to the existence } \\
\text { of A. aegypti are affected by } \\
\text { climate change. Especially } \\
\text { in the Caribbean and } \\
\text { Andean region. }\end{array}$ \\
\hline $\begin{array}{l}\text { Dejene W. Sintayehu, } \\
\text { Nega Tassie, Willem F. } \\
\text { De Boer (27) }\end{array}$ & $\begin{array}{l}\text { Present and Future } \\
\text { Climatic Suitability for } \\
\text { Dengue Fever in Africa }\end{array}$ & Case Study & $\begin{array}{l}753 \text { data of A. } \\
\text { aegypti, } 62 \text { data on } \\
\text { the incidence of } \\
\text { DHF, and bioclimatic } \\
\text { variables. }\end{array}$ & $\begin{array}{l}\text { Climate scenarios RCP } 4.5 \text { and RCP } \\
8.5 \text { predict that in } 2050 \text { the area that is } \\
\text { comfortable for Aedes aegypti in Africa } \\
\text { will increase by } 21.8 \% \text { and } 23.3 \% \text {, and } \\
\text { will continue to increase until } 2070 \text {. }\end{array}$ & $\begin{array}{l}\text { Due to climate change, } \\
\text { the incidence of dengue is } \\
\text { expected to increase in some } \\
\text { areas of Africa. }\end{array}$ \\
\hline $\begin{array}{l}\text { Amaury de Souza, } \\
\text { Marcel Carvalho Abreu, } \\
\text { Jose Francisco Oliveira- } \\
\text { Junior (47) }\end{array}$ & $\begin{array}{l}\text { Impact of Climate } \\
\text { Change on Human } \\
\text { Infectious Diseases: } \\
\text { Dengue }\end{array}$ & $\begin{array}{l}\text { Descriptive and } \\
\text { Quantitative } \\
\text { Analysis }\end{array}$ & $\begin{array}{l}\text { Dengue cases from } \\
\text { SINAN (2008-2018) } \\
\text { and meteorological } \\
\text { data (2008-2018). }\end{array}$ & $\begin{array}{l}\text { The majority of dengue cases are } \\
\text { concentrated at the beginning of the } \\
\text { year, the rainy season. If the temperature } \\
\text { increases by one degree, the incidence of } \\
\text { DHF will increase by } 45 \% \text {. }\end{array}$ & $\begin{array}{l}\text { The increase in dengue } \\
\text { transmission may be caused } \\
\text { by high greenhouse gas } \\
\text { emissions that increase } \\
\text { temperature. }\end{array}$ \\
\hline $\begin{array}{l}\text { Satya Ganesh Kakarla, } \\
\text { Kantha Rao Bhimala, } \\
\text { Madhsudhan Rao Kadiri, } \\
\text { Sriram Kumaraswamy, } \\
\text { Srinivasa Rao Mutheneni } \\
\text { (38) }\end{array}$ & $\begin{array}{l}\text { Dengue Situation in } \\
\text { India: Suitability and } \\
\text { Transmission Potential } \\
\text { Model for Present } \\
\text { and Projected Climate } \\
\text { Change Scenarios }\end{array}$ & $\begin{array}{l}\text { Quantitative } \\
\text { analysis of } \\
\text { secondary data. }\end{array}$ & $\begin{array}{l}\text { Clinically diagnosed } \\
\text { dengue data from } \\
1998 \text { to } 2018 \text { from } \\
\text { NVBDCP and climate } \\
\text { data from the ESRL } \\
\text { Website. }\end{array}$ & $\begin{array}{l}\text { There is an additional area that becomes } \\
\text { a suitable place as a location for DHF } \\
\text { transmission. The increase in the average } \\
\text { temperature causes this. The post- } \\
\text { monsoon period is predicted to have a } \\
\text { high probability of transmission of DHF. }\end{array}$ & $\begin{array}{l}\text { The increase in dengue } \\
\text { transmission may be caused } \\
\text { by high greenhouse gas } \\
\text { emissions that increase } \\
\text { temperature. }\end{array}$ \\
\hline
\end{tabular}
(2020)

\begin{tabular}{lll}
\hline Kristie L. Ebi, Joshua & Dengue in a Changing & Literature \\
Nealon (22) & Climate & Review
\end{tabular}

Climate change causes an increase in temperature, rainfall, and urbanization which is associated with an increase in the incidence of dengue and the risk of outbreaks.
The average daily temperature and temperature variations are two important factors influencing the incidence and spread of DHF.

\begin{tabular}{|c|c|c|c|c|c|}
\hline $\begin{array}{l}\text { Clement N. Mweya, } \\
\text { Sharaduli I. Kimera, } \\
\text { Grades Stanley, Gerald } \\
\text { Misinzo, Leonard E.G. } \\
\text { Mboera (50) }\end{array}$ & $\begin{array}{l}\text { Climate Change } \\
\text { Influences Potential } \\
\text { Distribution of Infected } \\
\text { Aedes aegypti Co- } \\
\text { Occurrence with } \\
\text { Dengue Epidemics } \\
\text { Risk Areas in Tanzania }\end{array}$ & $\begin{array}{l}\text { Experimental } \\
\text { Study }\end{array}$ & $\begin{array}{l}368 \text { mosquito pools } \\
\text { containing Aedes } \\
\text { aegypti and } 19 \\
\text { bioclimatic variables }\end{array}$ & $\begin{array}{l}\text { Of the } 19 \text { bioclimatic variables, only } \\
12 \text { variables could predict the spread of } \\
\text { Aedes aegypti. The probability of the } \\
\text { presence of Ae. aegypti appears in the } \\
\text { coastal areas and spreads towards the } \\
\text { central area. }\end{array}$ & $\begin{array}{l}\text { Climate change is the cause } \\
\text { of the increase in areas at } \\
\text { risk of dengue epidemics in } \\
\text { Tanzania. }\end{array}$ \\
\hline $\begin{array}{l}\text { Fajar Fatmawati and } \\
\text { Sulistyawati (51) }\end{array}$ & $\begin{array}{l}\text { Climate Change and } \\
\text { Dengue in Indonesia: a } \\
\text { Systematic Review }\end{array}$ & $\begin{array}{l}\text { Systematic } \\
\text { Literature } \\
\text { Review }\end{array}$ & - & $\begin{array}{l}\text { The majority of studies conducted in } \\
\text { endemic locations showed that climate } \\
\text { variables had a significant correlation } \\
\text { with dengue cases. Temperature is the } \\
\text { major factor that correlates with DHF } \\
\text { transmission. In addition to temperature, } \\
\text { there are also factors of rainfall, } \\
\text { humidity, and wind speed. }\end{array}$ & $\begin{array}{l}\text { Adaptation and protection } \\
\text { from the impacts caused by } \\
\text { climate change, which is a } \\
\text { risk of dengue fever, need } \\
\text { to be developed by applying } \\
\text { the Early Warning System } \\
\text { (EWS), which refers to the } \\
\text { existing climate information. }\end{array}$ \\
\hline
\end{tabular}

Table 2. Characteristics of Studies Using RCP

\begin{tabular}{|c|c|c|c|c|c|c|}
\hline Author & Location & $\begin{array}{l}\text { Baseline } \\
\text { Period }\end{array}$ & $\begin{array}{l}\text { Projection } \\
\text { Period }\end{array}$ & $\begin{array}{l}\text { Climate } \\
\text { Change } \\
\text { Scenarios }\end{array}$ & $\begin{array}{l}\text { Modeling } \\
\text { Approach }\end{array}$ & Result \\
\hline $\begin{array}{l}\text { Callan Davis, Amanda K. } \\
\text { Murphy, Hillary Bambrick, } \\
\text { Gregor J. Devine, Francesca D. } \\
\text { Fentiu, Laith Yakob, et al (18) }\end{array}$ & $\begin{array}{l}\text { Australia, Indonesia, China, } \\
\text { Thailand, Vietnam, and the } \\
\text { Philippines }\end{array}$ & $2005-2016$ & $\begin{array}{l}2030,2050 \\
\text { and } 2070\end{array}$ & $\begin{array}{l}\text { RCP4.5, } \\
\text { RCP6.0, and } \\
\text { RCP8.5 }\end{array}$ & Correlative & $\begin{array}{l}\text { The convenience of vectors in } \\
\text { spreading in these } 6 \text { countries will } \\
\text { remain high or decrease slightly. }\end{array}$ \\
\hline $\begin{array}{l}\text { Cristiam Victoriano Portilla } \\
\text { Cabrera, John Josephraj } \\
\text { Selvaraj (26) }\end{array}$ & Colombia & $1950-2000$ & 2050 and 2070 & $\begin{array}{l}\mathrm{RCP} 2.6, \\
\mathrm{RCP} 4.5 \text {, and } \\
\mathrm{RCP} 8.5\end{array}$ & Correlative & $\begin{array}{l}\text { In } 2050 \text { the ideal area for vector } \\
\text { breeding will increase, while in } \\
2070 \text {, it will decrease. }\end{array}$ \\
\hline
\end{tabular}




\begin{tabular}{|c|c|c|c|c|c|c|}
\hline Author & Location & $\begin{array}{l}\text { Baseline } \\
\text { Period }\end{array}$ & $\begin{array}{l}\text { Projection } \\
\text { Period }\end{array}$ & $\begin{array}{l}\text { Climate } \\
\text { Change } \\
\text { Scenarios }\end{array}$ & $\begin{array}{l}\text { Modeling } \\
\text { Approach }\end{array}$ & Result \\
\hline $\begin{array}{l}\text { Dejene W. Sintayehu, Nega } \\
\text { Tassie, Willem F. De Boer (27) }\end{array}$ & Africa & $1950-2000$ & 2050 and 2070 & $\begin{array}{l}\text { RCP4.5 and } \\
\text { RCP8.5 }\end{array}$ & Correlative & $\begin{array}{l}\text { The incidence of DHF will } \\
\text { increase in East, Central, and West } \\
\text { Africa. }\end{array}$ \\
\hline $\begin{array}{l}\text { Satya Ganesh Kakarla, Kantha } \\
\text { Rao Bhimala, Madhsudhan Rao } \\
\text { Kadiri, Sriram Kumaraswamy, } \\
\text { Srinivasa Rao Mutheneni (38) }\end{array}$ & India & $1901-2005$ & $2006-2100$ & $\begin{array}{l}\text { RCP4.5 and } \\
\text { RCP8.5 }\end{array}$ & Mechanistic & $\begin{array}{l}\text { Emissions from greenhouse gases } \\
\text { have the potential to increase the } \\
\text { spread of vectors. }\end{array}$ \\
\hline $\begin{array}{l}\text { Bipin Kumar Acharaya, } \\
\text { Chunxiang Cao, Min Xu, } \\
\text { Laxman Khanal, Shahid } \\
\text { Naeem, Shreejana Pandit (52) }\end{array}$ & Nepal & $1950-2000$ & 2050 and 2070 & $\begin{array}{l}\text { RCP2.6, } \\
\text { RCP6.0, and } \\
\text { RCP8.5 }\end{array}$ & Correlative & $\begin{array}{l}\text { As many as } 70 \% \text { of the population } \\
\text { is now at risk of dengue infection } \\
\text { and will increase to } 90 \% \text { in the } \\
\text { future. }\end{array}$ \\
\hline
\end{tabular}

\section{Relationship of Climate Factors and Aedes Aegypti}

The relationship between climate and infectious diseases depends on accuracy, long-term, and previously available disease incidence data. Aedes aegypti mosquitoes are a common vector in urban environments in tropical or subtropical countries. This fact can be seen from their habit of laying eggs in containers filled with artificial or natural water, and these eggs can survive even with a small amount of water (19).

Aedes aegypti Mosquitoes live comfortably in areas with tropical and subtropical climates because these areas have suitable temperatures for them to live and breed. Warm temperatures increase the lifespan of adult mosquitoes and shorten the incubation period of the virus in the vector or during transmission methods (20). Research conducted using mosquito traps with rainfall anomalies found that the number of mosquito eggs will increase in extreme rainfall. This started with flooding, which caused puddles of water in several locations for mosquitoes to lay eggs (21). In some areas, the incidence of DHF is influenced by humidity and vapor pressure. In addition to temperature, rainfall, and wind speed, humidity is also one of the weather variables that can predict the intensity and timing of dengue outbreaks. Humidity has the potential to affect the biting behavior, adaptation, and survival of mosquitoes. However, this fact does not attract the attention of most researchers (22).

In one of the research articles conducted in Indonesia, a tropical country, a cross-sectional study design was conducted to find the relationship between three climate variables and the incidence of DHF. The Spearman correlation analysis results showed an analysis of the relationship of five climatic factors consisting of humidity, temperature, maximum and minimum values of temperature, rainfall, and rainy days. The results show that humidity has a positive correlation with the incidence of DHF ( $p<0.001 ; r=0.458)$, the same correlation results also occur on rainy days $(p<0.001 ; r=0.429)$ and rainfall $(0<0.001 ; r=0.428)$. Different results were obtained from the temperature variable $(p=0.407$ $; r=0.086)$ and the maximum and minimum values of temperature $(p=0.06 ; r=-0.278)$, both of which had no correlation with the incidence of DHF (23). These results are also supported by the results of research conducted in Kalimantan in 2018, getting a p-value = 0.002 in the analysis of the relationship between rainfall and the incidence of DHF, which indicates a relationship between the two variables (17).

\section{Temperature and The Incidence of DHF}

Temperature is a climatic factor that can affect various mechanisms of disease transmission, such as air-borne disease, vector-borne disease, food-borne disease, and bacteria (19). Temperature can lengthen and shorten the life span of a vector while it is still in the pupa stage, so the dependence is very high (24). In some other areas, the temperature is too low for mosquitoes to survive in the winter. The selected study stated that an increase in temperature reduces the potential for dengue epidemics in the tropics which the average temperature up to $29^{\circ} \mathrm{C}$ triggers an increase in the potential for DHF occurrences, while temperatures below $29^{\circ} \mathrm{C}$ reduce it (25).

As in Colombo, through modeling using MaxEnt, it was concluded that the Caribbean and the Andeans are vulnerable to the presence of Aedes aegypti affected by climate change (26). In African countries, the temperature is the most important climatic variable influencing the Aedes aegypti, which resulted in DHF incidence at $70.8 \%$. At high temperatures, bionomic mosquito-biting behavior increases (27). A study in Jakarta, Indonesia, showed a significant correlation between temperature and the incidence of DHF in 20082016 because temperature affects mosquito reproduction and survival (28). A retrospective study was conducted in Jeddah regarding the relationship between the average temperature in one month, and the incidence of DHF in high fever patients showed that the two variables had a positive association (29). 
The low temperature in an area will affect the survival of adult mosquitoes, affecting the rate of transmission (30-31). In addition to low temperatures, extreme temperatures also cause the death of mosquito larvae, from research conducted by observing at a temperature of $37^{\circ} \mathrm{C}$ (32). From the identification results carried out in Europe, it was found that in the present, past, and future times, the potential for transmission of dengue disease can be predicted based on temperature or daily variations in temperature (33). Most of the overall DHF incidence variance can be explained by the temperature aspect (34).

\section{Rainfall and The Incidence of DHF}

The risk of dengue incidence increases significantly during the rainy season (35). In a study conducted in a tropical country, it was found that there was a strong correlation between the average weekly rainfall and the number of mosquito larvae. A significant correlation was also found between identified cases of DHF and rainfall in the last four weeks (36). The increase in the number of mosquito eggs will produce new vector seeds. When the rainy season comes, it can increase air humidity and cause an increase in mosquito nesting sites (28).

In a study conducted in Jakarta, the occurrence of rainfall $>200 \mathrm{~mm}$ at the beginning of the year was followed by an increase in the incidence of DHF, precisely in January-April (28), which affects the relative risk (37-38). Countries with the same temperature and rainfall figures are very suitable for the spread of dengue infection in current and future climatic conditions (27). In contrast, with studies that have been conducted in Indonesia, Taiwan, and Malaysia, it was concluded that there is no relationship between rainfall and an increased risk of DHF incidence (32,39-40). Research conducted in Taiwan found that high rainfall does not necessarily affect mosquito density because mosquito eggs and larvae will be carried away by rainwater flows from where they lay their eggs. This explains the decrease in the incidence of dengue fever in northern Taiwan when rainfall is increasing.

\section{Humidity and The Incidence of DHF}

Humidity has a relationship with anomalous mortality and morbidity through its ability to affect heat stress and hydration. Humidity is also classified as an environmental factor related to the topic of human health. The occurrence of high humidity is the result of a combination of rainfall and high temperature (41).
Mentioned in a study that humidity is the strongest climatic factor that affects the incidence of DHF. At low humidity levels, mosquitoes do not get enough time to transfer the virus from the stomach to the salivary glands. Therefore, mosquitoes need humidity levels above $60 \%$ to live longer and produce more eggs (42). Meanwhile, high humidity levels will increase the lifespan of adult mosquitoes, and it will affect the incubation period of the virus to be shorter and increase the intensity of transmission (20).

A study in China found indications that high humidity can increase the DHF risk (43). A similar study conducted in India, using a retrospective study, also found that the humidity rate for the last two months impacted the DHF incidence (44). Research conducted in Serang City examined the humidity level with the incidence of DHF with the Spearman correlation test, showing a significant correlation with $p=0.408$ between the two variables (45). However, there are also contradictory research results stating that there is no significant relationship between air humidity and the incidence of DHF. It was continued that humidity did not directly impact the incidence of DHF but was sufficient to impact the lifespan of Aedes aegypti (46). Humidity can be used as one of the calculations to predict the influence of climate change on the potential increase in the incidence of dengue fever in tropical countries.

\section{Impact of Climate Change on The Incidence of DHF.}

In the future, climate change will cause changes in the geographical distribution of animal species, as is the current picture of polar bear starvation, presented by the National Geographic Society in December 2017. There is already a wealth of evidence from research on how climate change has affected the pathogen-vector-host system (14). Climate change can affect the transmission of infectious diseases by changing the pattern of transmission between humans, pathogens, vectors, and hosts (47). In recent decades, DHF has increasingly spread to new areas that were previously only endemic in certain areas. In a subtropical country such as India, in 2015 , there was an outbreak that became the worst outbreak since 2006, with more than 15,000 cases (25). Researchers can use various research methods and data to determine the impact of climate change on the incidence of DHF in the future. For example, in a study conducted in India and Africa, they used Representative Concentration Pathways (RCP) data provided by the IPCC, then the data was combined with data on the incidence of DHF in their respective countries. From 
research conducted to estimate the future impact of DHF with dynamic modeling in the Southeastern United States, it was found that there is potential that climate change will affect the virus and associated vectors. Some areas will experience an increased risk of disease and an increase in the number of vectors, while others will only experience an increase in the population of Aedes aegypti but with less transmission (48).

In India, climate change between the years 19801999 and 2000-2017 affects the potential for an increase in dengue transmission. In the two spans of the year, there was an increase in the average temperature in India. The potential for increased DHF transmission was analysed using a greenhouse gas effect scenario (38). Climate change can affect dengue incidence, which is predicted to increase in the eastern, central, and western regions of Africa. Areas suitable for Aedes aegypti will shift to higher ground, where large human populations live (27). In a study conducted using the ensemble boosted regression tree method in 2019, a map of the environment scope that was suitable for DHF incidences around the world was drawn, then we get an overview of the results of predictions made regarding changes on a global area scale to the risk of DHF incidence based on references from RCP6.0 and SSP in 2015, 2050, and 2080. There is a small but significant change in the distribution of risk on a subnational scale between 2015 and 2080 (49).

By studying or analysing the conditions of temperature and rainfall in the next few years, the results can be used as a reference for estimates of the possible transmission of the mosquito vector Aedes aegypti. There is still a need for other studies that can explain further the effect of climate change as one of the risk factors that can increase the incidence of DHF in tropical countries, taking into account the time interval. In addition to climate change, other factors can increase the risk of dengue transmissions, such as socio-demographic, economic status, culture, and human behavior.

\section{ACKNOWLEDGEMENTS}

The author is very grateful to all parties in the Department of Environmental Health, Faculty of Public Health, Airlangga University, who have helped prepare this manuscript.

\section{CONCLUSION}

Based on the explanation above, it can be concluded that climate change, such as an increase in temperature from low to high or vice versa that occurs for several years on this earth, can increase the potential risk of dengue fever throughout the world, it can even spread to new areas that were not previously dengueendemic areas. Qualitative and quantitative research methods can predict the impact of climate change on the incidence of DHF, such as case studies, experimental studies, and literature reviews.

\section{REFERENCES}

1. Tran BL, Tseng WC, Chen CC, Liao SY. Estimating the Threshold Effects of Climate on Dengue: A Case Study of Taiwan. Int J Environ Res Public Health. 2020;17(4):1-17. https://doi.org/10.3390/ ijerph17041392

2. Cucunawangsih, Lugito NPH. Trends of Dengue Disease Epidemiology. Virology. 2017;8(1):1-6. https://doi.org/10.1177/1178122X17695836

3. World Health Organization. Dengue and severe dengue. Geneve: World Health Organization; 2021 https://www.who.int/news-room/fact-sheets/detail/ dengue-and-severe-dengue

4. Samal RR, Gupta S, Kumar S. An Overview of Factors Affecting Dengue Transmission in Asian Region and Its Predictive Models. J Appl Nat Sci. 2020;12(3):460-470. https://doi.org/10.31018/jans. v12i3.2360

5. Jing QL, Cheng Q, Marshall JM, Hu WB, Yang ZC, Lu JH. Imported Cases and Minimum Temperature Drive Dengue Transmission in Guangzhou, China: Evidence from ARIMAX model. Epidemiology and Infection. 2018;146(10):1226-1235. https://doi. org/10.1017/S0950268818001176

6. Satoto TBT, Alvira N, Wibawa T, Diptyanusa A. Controlling Factors that Potentially Against Transmission of Dengue Hemorrhagic Fever at State Elementary Schools in Yogyakarta. Kesmas. 2017;11(4):178-184. http://dx.doi.org/10.21109/ kesmas.v11i4.1248

7. Mordecai EA, Cohen JM, Evans M V, Gudapati P, Johnson LR, Lippi CA, et al. Detecting the Impact of Temperature on Transmission of Zika, Dengue, and Chikungunya Using Mechanistic Models. PLoS Negl Trop Dis. 2017;11(4):1-18. https://doi. org/10.1371/journal.pntd.0005568

8. Ogden NH, Lindsay LR. Effects of Climate and Climate Change on Vectors and Vector-Borne Diseases: Ticks Are Different. Trends Parasitol. 2016;32(8):646-656. http://dx.doi.org/10.1016/j. pt.2016.04.015

9. National Geographic Society. Climate Change. Washington: National Geographic Society. https:// www.nationalgeographic.org/encyclopedia/climatechange/

10. Intergovernmental Panel on Climate Change (IPCC). Special Report on Climate Change and Land. Geneva: Intergovernmental Panel on Climate Change; 2019. https://www.ipcc.ch/srccl/

11. Intergovernmental Panel on Climate Change (IPCC). Technical Summary: Special Report on Climate Change and Land. Geneva: Intergovernmental Panel on Climate Change; 2019. https://www.ipcc. ch/srccl/chapter/technical-summary/ 
12. World Health Organization. Climate Change and Health. Geneva: World Health Organization; 2018. https://www.who.int/news-room/fact-sheets/detail/ climate-change-and-health

13. de Vries S, Snep R. Biodiversity in the Context of 'Biodiversity - Mental Health' Research. Biodiversity and Health in the Face of Climate Change. Switzerland: Springer Cham; 2019. 159-173 p. https://doi.org/10.1007/978-3-030-02318-8 8

14. Caminade $\mathrm{C}$, Mclntyre KM, Jones AE. Impact of Recent and Future Climate Change on Vector-Borne Diseases. Ann N Y Acad Sci. 2019;1436(1):157173. https://doi.org/10.1111/nyas.13950

15. Iwamura T, Guzman-Holst A, Murray KA. Accelerating Invasion Potential of Disease Vector Aedes aegypti Under Climate Change. Nat Commun. 2020;11(2130):1-10. http://dx.doi. org/10.1038/s41467-020-16010-4

16. Aadil Gulzar, Tajamul Islam, Ruquia Gulzar, Tabasum Hassan. Climate Change and Impacts of Extreme Events on Human Health: An Overview. Indones J Soc Environ Issues. 2021;2(1):68-77. https://doi.org/10.47540/ijsei.v2i1.180

17. Ishak NI, Kasman K. the Effect of Climate Factors for Dengue Hemorrhagic Fever in Banjarmasin City, South Kalimantan Province, Indonesia, 2012-2016. Public Heal Indones. 2018;4(3):121-128. http:// dx.doi.org/10.36685/phi.v4i3.181

18. Davis C, Murphy AK, Bambrick H, Devine GJ, Frentiu FD, Yakob L, et al. A Regional Suitable Conditions Index to Forecast The Impact of Climate Change on Dengue Vectorial Capacity. Environ Res. 2021;195(110849):1-9. https://doi.org/10.1016/j. envres.2021.110849

19. Madeleine CT, Simon JM. Climate Information For Public Health Action. Routledge: Climate Information For Public Health Action; 2018. https://www.taylorfrancis.com/books/oaedit/10.4324/9781315115603/climate-informationpublic-health-action-thomson-madeleine-masonsimon

20. Mutheneni SR, Morse AP, Caminade C, Upadhyayula SM. Dengue Burden in India: Recent Trends and Importance of Climatic Parameters. Emerg Microbes Infect. 2017;6(1):1-10. http:// dx.doi.org/10.1038/emi.2017.57

21. Nosrat C, Altamirano J, Anyamba A, Caldwell JM, Damoah R, Mutuku F, et al. Impact of Recent Climate Extremes on Mosquito-Borne Disease Transmission in Kenya. PLoS Negl Trop Dis. 2021;15(3):1-17. http://dx.doi.org/10.1371/journal. pntd.0009182

22. Ebi KL, Nealon J. Dengue in A Changing Climate. Environ Res. 2016;151(1):115-123. http://dx.doi. org/10.1016/j.envres.2016.07.026

23. Kesetyaningsih TW, Fauzan RA. The Relationship Between Climate Factors and Dengue Hemorrhagic Fever Incidence in Sleman, Yogyakarta. 4th Int Conf Sustain Innov 2020-Health Sci Nurs. 2021;33(1):614-619. $\quad$ https://doi.org/10.2991/ ahsr.k.210115.116
24. Sun H, Jit M, Cook AR, Carrasco LR, Dickens BL. Determining Environmental and Anthropogenic Factors Which Explain the Global Distribution of Aedes aegypti and Ae. Albopictus. BMJ Glob Heal. 2018;3(4):1-11. http://dx.doi.org/10.1136/bmigh2018-000801

25. Helmersson JL. Climate Change, Dengue and Aedes Mosquitoes: Past Trends and Future Scenarios. Dissertation. Sweden: Umea University. 2018. http://urn.kb.se/resolve?urn=urn:nbn:se:umu:diva143764

26. Portilla Cabrera CV, Selvaraj JJ. Geographic Shifts in The Bioclimatic Suitability for Aedes aegypti Under Climate Change Scenarios in Colombia. Heliyon. 2020;6(1):e03101. https://doi. org/10.1016/j.heliyon.2019.e03101

27. Sintayehu DW, Tassie N, De Boer WF. Present and Future Climatic Suitability for Dengue Fever in Africa. Infect Ecol Epidemiol. 2020;10(1). https:// doi.org/10.1080/20008686.2020.1782042

28. Hasanah H, Susanna D. Weather Implication for Dengue Fever in Jakarta, Indonesia 2008-2016. KnE Life Sci. 2019;4(10):184-192. https://doi. org/10.18502/kls.v4i10.3719

29. Hashem AM, Abujamel T, Alhabbab R, Almazroui M, Azhar El. Dengue Infection in Patients with Febrile Illness and Its Relationship to Climate Factors: A Case Study in The City of Jeddah, Saudi Arabia, for the period 2010-2014. Acta Trop. 2018;181(1):105-111. https://doi.org/10.1016/j. actatropica.2018.02.014

30. Komaling D, Sumampouw OJ, Sondakh RC, Kesehatan F, Universitas M, Ratulangi S. Determinan Kejadian Demam Berdarah Dengue di Kabupaten Minahasa Selatan Tahun 2016-2018. $J$ Public Heal Community Med. 2020;1(1):57-64. https://doi.org/10.35801/ijphcm.1.1.2020.27247

31. Chadee DD, Martinez R. Aedes aegypti (L.) in Latin American and Caribbean Region: With Growing Evidence for Vector Adaptation to Climate Change?. Acta Trop. 2016;156(1):137-143. http:// dx.doi.org/10.1016/j.actatropica.2015.12.022

32. Sukiato F, Wasserman RJ, Foo SC, Wilson RF, Cuthbert RN. The Effects of Temperature and Shading on Mortality and Development Rates of Aedes aegypti (Diptera: Culicidae). J Vector Ecol. 2019;44(2):264-270. https://doi.org/10.1111/ jec. 12358

33. Liu-Helmersson J, Quam M, Wilder-Smith $A$, Stenlund H, Ebi K, Massad E, et al. Climate Change and Aedes Vectors: 21st Century Projections for Dengue Transmission in Europe. EBioMedicine. 2016;7(1):267-277. http://dx.doi.org/10.1016/j. ebiom.2016.03.046

34. Arcari P, Tapper N. The Variable Impact of ENSO Events on Regional Dengue/DHF in Indonesia. Singap J Trop Geogr. 2017;38(1):5-24. https://doi. org/10.1111/sjtg. 12179

35. Pasin C, Halloran ME, Gilbert PB, Langevin E, Ochiai RL, Pitisuttithum P, et al. Periods of High Dengue Transmission Defined by Rainfall Do Not 
Impact Efficacy of Dengue Vaccine in Regions of Endemic Disease. PLoS One. 2018;13(12):1-16. https://doi.org/10.1371/journal. pone.0207878

36. Ahmad R, Suzilah I, Najdah WMAW, Topek O, Mustafakamal I, Lee HL. Factors Determining Dengue Outbreak in Malaysia. PLOS One. 2018;13(2):1-13. https://doi.org/10.1371/ journal. pone.0193326

37. Iguchi JA, Seposo XT, Honda Y. Meteorological Factors Affecting Dengue Incidence in Davao, Philippines. BMC Public Health. 2018;18(1):1-10. https://doi.org/10.1186/s12889-018-5532-4

38. Kakarla SG, Bhimala KR, Kadiri MR, Kumaraswamy $S$, Mutheneni SR. Dengue Situation in India: Suitability and Transmission Potential Model for Present and Projected Climate Change Scenarios. Sci Total Environ. 2020;739(140336):1-12. https:// doi.org/10.1016/i.scitotenv.2020.140336

39. Ghaisani NP, Lucia M, Lusida I. Correlation between Climate Factors with Dengue Hemorrhagic Fever Cases in Surabaya 2007-2017. Indonesian Journal of Tropical and Infectious Disease. 2021;9(1):3944. http://dx.doi.org/10.20473/ijtid.v9i1.16075

40. Lai YH. The Climatic Factors Affecting Dengue Fever Outbreaks in Southern Taiwan: An Application of Symbolic Data Analysis. Biomed Eng Online. 2018;17(S2):1-14. https://doi.org/10.1186/s12938018-0575-4

41. Davis RE, McGregor GR, Enfield KB. Humidity: A Review and Primer on Atmospheric Moisture and Human Health. Environ Res. 2016;144(1):106-116. http://dx.doi.org/10.1016/j.envres.2015.10.014

42. Putri WA, Rohiman A, Sulistiawati S, Puspitasari D. Effects of Climatic Factors on The Incidence Rate of Dengue Virus Infection in Surabaya During 20102013. Biomol Heal Sci J. 2019;2(1):36-40. http:// dx.doi.org/10.20473/bhsj.v2i1.9340

43. Xiao J, Liu T, Lin H, Zhu G, Zeng W, Li X, et al. Weather Variables and the El Niño Southern Oscillation May Drive the Epidemics of Dengue in Guangdong Province, China. Sci Total Environ. 2018;624(1):926-934. https://doi.org/10.1016/j. scitotenv.2017.12.200

44. Pol SS, Rajderkar SS, Dhabekar PD, Bansode Gokhe SS. Effect of Climatic Factors Like Rainfall,
Humidity and Temperature on The Dengue Cases in The Metropolitan City of Maharashtra. Int J Community Med Public Heal. 2021;8(2):672677. https://dx.doi.org/10.18203/2394-6040. ijcmph20210220

45. Alizkan U. Analisis Korelasi Kelembaban Udara Terhadap Epidemi Demam Berdarah yang Terjadi di Kabupaten dan Kota Serang. Gravity. 2017;3(1):2329. http://dx.doi.org/10.30870/gravity.v3i1.2409

46. Arieskha FTA, Rahardjo M, Joko T. The Association between Weather Variability and Dengue Hemorrhagic Fever in Tegal Regency. J Kesehat Lingkung. 2019;11(4):339-347. http://dx.doi. org/10.20473/jkl.v11i4.2019.339-347

47. Haikerwal A, Saxena SK. Impact of Climate Change on Water-Associated Infectious Diseases. Brazilian Archives of Biology and Technology. 2019;64(1):5362. https://doi.org/10.1590/1678-4324-2021190502

48. Butterworth MK, Morin CW, Comrie AC. An Analysis Of The Potential Impact Of Climate Change On Dengue Transmission In The Southeastern United States. Environ Health Perspect. 2017;125(4):579_ 585. https://doi.org/10.1289/EHP218

49. Messina JP, Brady OJ, Golding N, Kraemer MUG, Wint GRW, Ray SE, et al. The Current and Future Global Distribution and Population at Risk of Dengue. Nat Microbiol. 2019;4(9):1508-15015. http://dx.doi.org/10.1038/s41564-019-0476-8

50. Mweya CN, Kimera SI, Stanley G, Misinzo G, Mboera LEG. Climate Change Influences Potential Distribution of Infected Aedes aegypti CoOccurrence with Dengue Epidemics Risk Areas in Tanzania. PLoS One. 2016;11(9):1-13. https://doi. org/10.1371/journal.pone.0162649

51. Fatmawati F, Sulistyawati S. Climate Change and Dengue in Indonesia: a Systematic Review. Epidemiol Soc Heal Rev. 2019;1(1):29-40. https:// doi.org/10.26555/eshr.v1i1.938

52. Acharya BK, Cao C, Xu M, Khanal L, Naeem $S$, Pandit S. Present and Future of Dengue Fever in Nepal: Mapping Climatic Suitability by Ecological Niche Model. Int J Environ Res Public Health. 2018;15(2):1-15. https://doi.org/10.3390/ ijerph15020187 